\title{
Web-Based Smart Market Applications as a Preference Transition during COVID-19 Pandemic
}

\author{
Ika Oktavia Suzanti, Fifin Ayu Mufarroha*, Jauhari, Imamah \\ Faculty of Engineering, University of Trunojoyo Madura, 69162, Indonesia
}

\begin{abstract}
The Smart Market application is a web application that useful for making easier of traders and consumers to carry out buying and selling activities in the midst of the COVID-19 pandemic. In advances technology, it is very relevant to implement website-based buying and selling which is quite easy to reach. Hence these activities become more practical and efficient by online without leave the house and it can be seen by the wider community. Another advantage is that the public can see product price updates so that they can find out the price and prevent the market price of raw materials which tends to fluctuate and become a big government homework that never ends. With the increasingly competitive market competition, the Smart Market system was built to maintain the existence of traditional markets and retain customers who tend to like to shop online. The system has been built by proposing research methodologies including, analysis, design, implementation, and testing. The system has been tested to see the ability using black box techniques and it is found that all features have been running well in accordance with the expected results.
\end{abstract}

Keywords: Smart Market; Covid-19 pandemic; Web Application; Shopping Wisely.

\section{Introduction}

According to governments in various parts of the world, the Covid-19 pandemic is to limit crowds to prevent the spread of the Covid-19 virus, including the Indonesian government [1]-[4]. The virus that began to be detected in Indonesian territory in early March 2020 made the Indonesian government take several policies to reduce the number of crowds in the community[5][6]. The large-scale social application is the first policy taken by the Indonesian government to break the chain of the spread of COVID-19. This policy has an impact on several sectors ranging from education [7]-[12], economic [13]-[15], society[16][17], offices [17][20]and traditional traders are no exception [21]. Traditional traders feel the effects of this policy the most, ranging from operational restrictions, reduced consumers, difficulty in accessing middlemen to a significant decline in turnover. This happens because the majority of traditional traders have not been able to adapt to technological developments which is one of the strategic choices to survive in the midst of a pandemic. The pandemic has also harmed some housewives who are often confused by the price of basic commodities in the market which tends to fluctuate on the grounds that basic goods are scarce or market traders rarely sell. Other findings, as do observations of a wide range of online shop platforms, is very rare traders in traditional markets. This is different from the modern market/supermarket which is becoming available on well-known online shopping platforms. The opportunities for traditional traders which are quite large have not been able to be optimized properly because there is no available container. Based on problems that have been formulated, we propose a web-based system with the title Smart Market.

This study aims to define and explain in more detail about the web-based application smart market which aims to make it easier for sellers to market or sell their products to a wider range of consumers. As well as educating the public that finding basic food materials can be made easier by using a web-based application smart market. In this web-based smart market application, it will also always be updated in displaying the price per product. So it is very useful for consumers to find out whether or not there is a price spike. The development of this system is expected to be a consideration, especially for traders because with the existence of a smart market system, traders or sellers can expand their marketing scope so that they can get more consumers. Apart from that, it is also beneficial for consumers, such as housewives, in fulfilling their daily needs. As for related agencies, it can be used as a guideline for the price range in the market so as to minimize fraud in raw material prices.

\footnotetext{
* Corresponding author : fifin.mufarroha@trunojoyo.ac.id
} 


\section{Methodology}

The development of this system implements several stages that are carried out. In general, the details of the work can be seen in Figure 1.

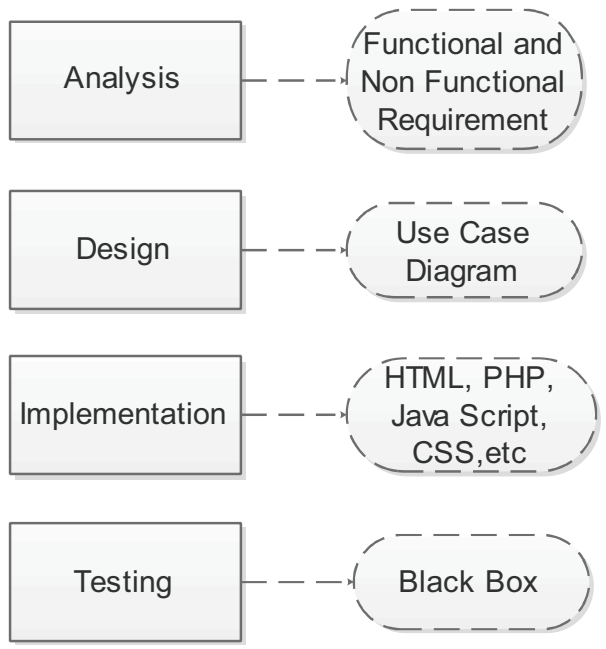

Fig. 1. Research Methodology.

The stages applied are the stages commonly used in system development including analysis, design, implementation, and testing. First, it begins with formulating the functional and non-functional requirements of the system to underlie development. Both formulations are carried out at the analysis stage. Based on the functional requirements, a system design is built which is a blueprint for the system procedure map, it can also describe the activities of the system, actors, and the relationship between them. The conversion of the mapping into the selected programming language is carried out at the implementation stage. To find out all the functions are running well, it needs to be tested.

\section{Results and Discussion}

\subsection{Analysis}

This stage describes the system to be developed. The result is a needs analysis which writes down the activities in the system that are needed by the user [22]. Two requirements are described, namely functional requirements and non-functional requirements which are shown in Table 1 and Table 2

Table 1. Functional Requirement

\begin{tabular}{|l|l|}
\hline \multicolumn{1}{|c|}{ Feature } & \multicolumn{1}{c|}{ Description } \\
\hline Logout & $\begin{array}{l}\text { The system directs the user to exit the } \\
\text { system. }\end{array}$ \\
\hline Login & $\begin{array}{l}\text { The system displays the start page when } \\
\text { opening the website, this feature serves } \\
\text { to provide access to users so that they } \\
\text { can enjoy the features/services on the } \\
\text { system. This feature can also be used as } \\
\text { system security, so that users and admins } \\
\text { do not hesitate to use it. }\end{array}$ \\
\hline
\end{tabular}

\begin{tabular}{|l|l|}
\hline Home & $\begin{array}{l}\text { The system displays the start page by } \\
\text { providing product information and prices }\end{array}$ \\
\hline $\begin{array}{l}\text { Product } \\
\text { Category }\end{array}$ & $\begin{array}{l}\text { The system displays the products } \\
\text { according to the user-defined type }\end{array}$ \\
\hline Search & $\begin{array}{l}\text { The system performs a product search } \\
\text { according to the keywords entered by the } \\
\text { user }\end{array}$ \\
\hline Cart & $\begin{array}{l}\text { The system can save and add the desired } \\
\text { item in the shopping cart to buy it later. }\end{array}$ \\
\hline Checkout & $\begin{array}{l}\text { The system displays a page containing } \\
\text { transactions between stores and } \\
\text { customers who want to buy the products } \\
\text { provided. }\end{array}$ \\
\hline
\end{tabular}

Tabel 2. Non-Functional Requirement

\begin{tabular}{|l|l|}
\hline \multicolumn{1}{|c|}{ Aspect } & \multicolumn{1}{|c|}{ Description } \\
\hline $\begin{array}{l}\text { Operasional } \\
\text { system }\end{array}$ & $\begin{array}{l}\text { The system will have a database to store } \\
\text { data and information on goods, } \\
\text { transactions, customers and suppliers. }\end{array}$ \\
\hline \multirow{3}{*}{ Security } & $\begin{array}{l}\text { The system will provide security to users } \\
\text { with usage management in the form of a } \\
\text { password that needs to be entered at the } \\
\text { beginning of using our system. The } \\
\text { existing data on the system will be safe } \\
\text { because it has been converted into digital } \\
\text { data and can be easily backed up } \\
\text { whenever needed. }\end{array}$ \\
\hline Interface & $\begin{array}{l}\text { The system can provide simple and user } \\
\text { friendly so that users can use the system } \\
\text { easily and comfortably }\end{array}$ \\
\hline Performance & $\begin{array}{l}\text { The system has a good speed, where } \\
\text { updates of related data will appear } \\
\text { immediately without excessive delay. }\end{array}$ \\
\hline
\end{tabular}

\subsection{Design}

Use case diagram is chosen as a diagram that represents the relationship between the system and the user[23][24]. Users are divided into 3 permissions, namely users, customers, and admins. Each actor has different permissions in the system which can be seen in Figure 2.

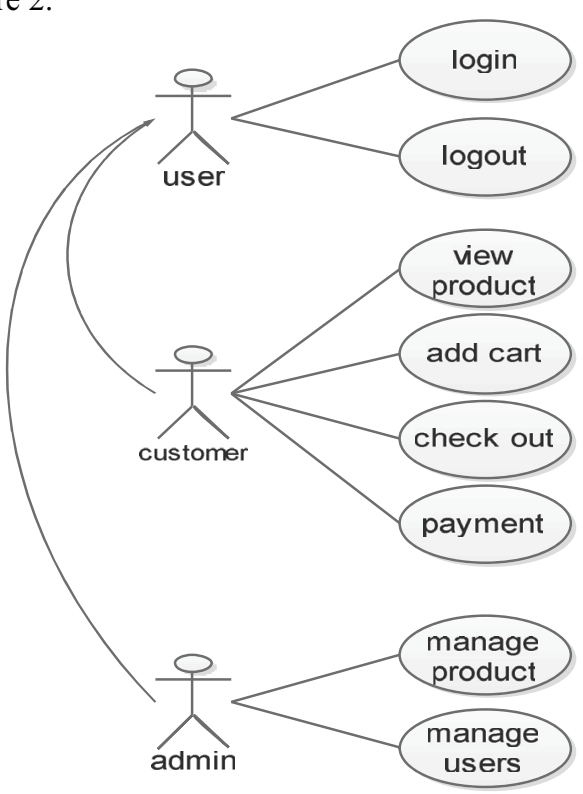

Fig. 2. Usecase Diagram 


\subsection{Implementation}

Implementation of the system using web-based programming languages such as PHP, CSS, JavaScript and several other supporting application programs. The application is run using a browser with a user friendly interface.

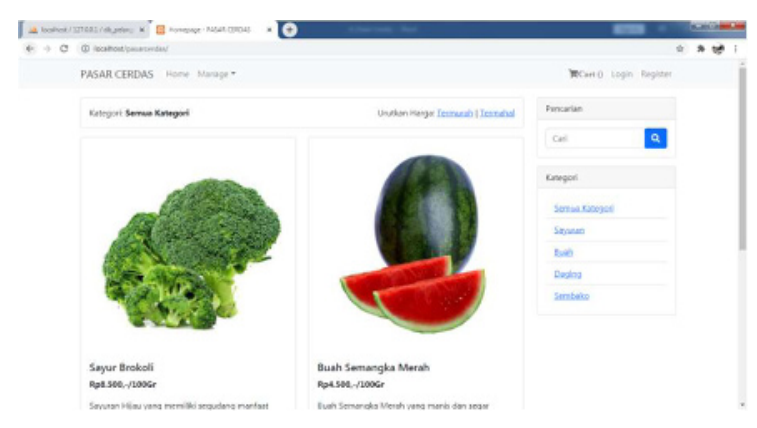

Fig. 3. Home page

Figure 3 is the home page where there are all available menus in Smart Market and on this page there is also a search feature to find the items needed and categories that function to filter products by type. Figure 4 shows the cart page, it can be seen that the selected product will be on this page accompanied by the quantity, price, total product. If the shopping process has been completed and the user wants to pay, the user will be redirected to the check page to make a transaction. The checkout page is shown in Figure 5.

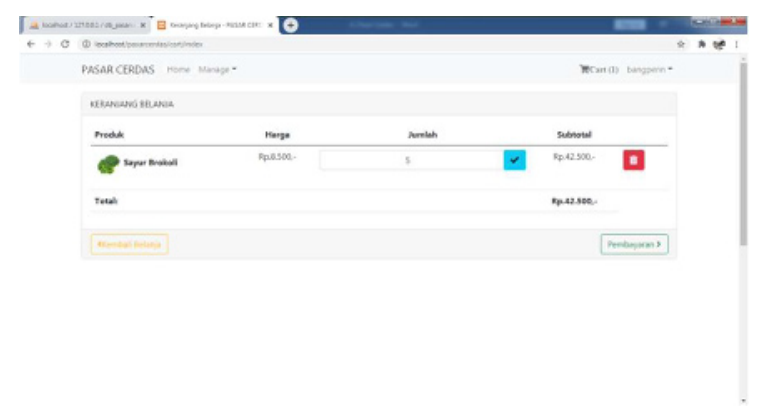

Fig. 4. Cart page

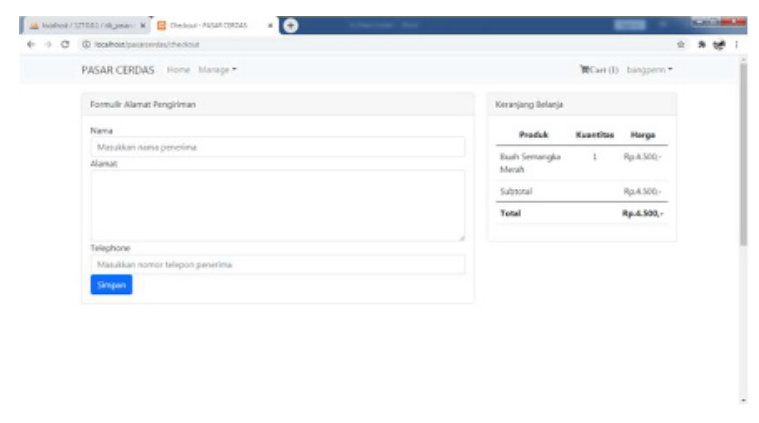

Fig. 5. Checkout page

\subsection{Testing}

The test is done by choosing the black box technique. This technique tests the functional requirements features that have been running according to the expected results.

Table 3. Black Box Testing

\begin{tabular}{|l|l|c|}
\hline \multicolumn{1}{|c|}{ Feature } & \multicolumn{1}{|c|}{ Expected Result } & $\begin{array}{c}\text { System } \\
\text { Result }\end{array}$ \\
\hline Logout & Displays login page & $\sqrt{ }$ \\
\hline Login & Displays the home page & $\sqrt{ }$ \\
\hline Home & Displays product details & $\sqrt{ }$ \\
\hline $\begin{array}{l}\text { Product } \\
\text { Category }\end{array}$ & Displays products filtered by type & $\sqrt{ }$ \\
\hline Search & Displays products by keyword & $\sqrt{ }$ \\
\hline Cart & $\begin{array}{l}\text { Displays purchased products along } \\
\text { with product details }\end{array}$ & $\sqrt{ }$ \\
\hline Checkout & Displays transaction process & $\sqrt{ }$ \\
\hline
\end{tabular}

\section{Conclusion}

This application is a smart market application for online shopping for daily needs during the pandemic. The application has been successfully built by applying the proposed research methodology. Predefined functional requirements with several features include, login, logout, homepage, product category, search, cart, and check out. In addition, non-functional aspects such as aspects of the operating system, security, interface, and system capabilities are also considered. Based on the needs analysis, the system is designed and implemented on a web-based basis. The system has been tested using the black box technique and it is known that all functions have been running well.

\section{References}

[1] T. Hale et al., "A global panel database of pandemic policies (Oxford COVID-19 Government Response Tracker)," Nat. Hum. Behav., vol. 5, no. 4, pp. 529-538, (2021), doi: 10.1038/s41562-021-01079-8.

[2] A. Dewi et al., "Global policy responses to the COVID-19 pandemic: proportionate adaptation and policy experimentation: a study of country policy response variation to the COVID-19 pandemic," Heal. Promot. Perspect., vol. 10, no. 4, pp. 359-365, Nov. (2020), doi: 10.34172/hpp.2020.54.

[3] E. Razumovskaia, L. Yuzvovich, E. Kniazeva, M. Klimenko, and V. Shelyakin, "The Effectiveness of Russian Government Policy to Support SMEs in the COVID-19 Pandemic," Journal of Open Innovation: Technology, Market, and Complexity, vol. 6, no. 4. (2020), doi: 10.3390/joitmc6040160.

[4] A. Altiparmakis, A. Bojar, S. Brouard, M. Foucault, H. Kriesi, and R. Nadeau, "Pandemic politics: policy evaluations of government responses to COVID-19," West Eur. Polit., vol. 44, no. 5-6, pp. 1159-1179, Sep. (2021), doi: $10.1080 / 01402382.2021 .1930754$. 
[5] A. Sukamto and S. Panca Parulian, "Religious Community Responses to the Public Policy of the Indonesian Government Related to the covid-19 Pandemic," J. Law, Relig. State, vol. 8, no. 2-3, pp. 273-283, (2020), doi: https://doi.org/10.1163/22124810-2020006.

[6] F. C. Permana, Z. M. Wicaksono, C. Kurniawan, A. S. Abdullah, and B. N. Ruchjana, "Perception analysis of the Indonesian society on twitter social media on the increase in BPJS kesehatan contribution in the Covid 19 pandemic era," J. Phys. Conf. Ser., vol. 1722, p. 12022, 2021, doi: 10.1088/17426596/1722/1/01(2022).

[7] C. P. Garris and B. Fleck, "Student evaluations of transitioned-online courses during the COVID-19 pandemic.," Scholarsh. Teach. Learn. Psychol., 2020, doi: 10.1037/st10000229.

[8] J. Zhou, "The role of libraries in distance learning during COVID-19," Inf. Dev., (2021), doi: $10.1177 / 02666669211001502$.

[9] J. J. Ratcliff, K. I. Minster, and C. Monheim, "Engaging students in an online format during the COVID-19 pandemic: A jury voir dire activity.," Scholarsh. Teach. Learn. Psychol., (2021), doi: 10.1037/st10000246.

[10] L. Santibañez and C. M. Guarino, "The Effects of Absenteeism on Academic and SocialEmotional Outcomes: Lessons for COVID-19," Educ. Res., pp. 1-9, (2021), doi: 10.3102/0013189X21994488.

[11] Y. Wiratomo and F. Mulyatna, "Use of Learning Management Systems in Mathematics Learning during a Pandemic," J. Math. Pedagog., vol. 1, no. 2, pp. 62-71, (2020).

[12] A. J. Azar et al., "Design, Implementation and Evaluation of a Distance Learning Framework to Expedite Medical Education during COVID19 pandemic: A Proof-of-Concept Study," J. Med. Educ. Curric. Dev., vol. 8, p. 238212052110003, (2021), doi: $10.1177 / 23821205211000349$.

[13] T. D. Pham, L. Dwyer, J.-J. Su, and T. Ngo, "COVID-19 impacts of inbound tourism on Australian economy," Ann. Tour. Res., vol. 88, p. 103179, 2021, doi: https://doi.org/10.1016/j.annals.(2021).103179.

[14] A. Sharif, C. Aloui, and L. Yarovaya, "COVID19 pandemic, oil prices, stock market, geopolitical risk and policy uncertainty nexus in the US economy: Fresh evidence from the wavelet-based approach," Int. Rev. Financ. Anal., vol. 70, p. 101496, (2020), doi: https://doi.org/10.1016/j.irfa.2020.101496.

[15] S. E. Obi, T. Yunusa, A. N. Ezeogueri-Oyewole, S. S. Sekpe, E. Egwemi, and A. S. Isiaka, "The Socio-Economic Impact of Covid-19 on The
Economic Activities of Selected States in Nigeria ," Indones. J. Soc. Environ. Issues, vol. 1, no. 2 SE-, pp. 39-47, Aug. (2020), doi: 10.47540/ijsei.v1i2.10.

[16] R. Cui, H. Ding, and F. Zhu, "Gender Inequality in Research Productivity During the COVID-19 Pandemic," Manuf. Serv. Oper. Manag., Jun. 2021, doi: 10.1287/msom.(2021).0991.

[17] Y. Zhai and X. Du, "Addressing collegiate mental health amid COVID-19 pandemic," Psychiatry Res., vol. 288, p. 113003, 2020, doi: https://doi.org/10.1016/j.psychres.(2020).1130 03.

[18] T. M. Yildirim and H. Eslen-Ziya, "The differential impact of COVID-19 on the work conditions of women and men academics during the lockdown," Gender, Work Organ., vol. 28, no. S1, pp. 243-249, Jan. (2021), doi: https://doi.org/10.1111/gwao.12529.

[19] Y. Xiao, B. Becerik-Gerber, G. Lucas, and S. C. Roll, "Impacts of Working From Home During COVID-19 Pandemic on Physical and Mental Well-Being of Office Workstation Users," $J$. Occup. Environ. Med., vol. 63, no. 3, pp. 181190, Mar. (2021), doi: 10.1097/JOM.0000000000002097.

[20] A. Nediari, C. Roesli, and P. M. Simanjuntak, "Preparing post Covid-19 pandemic office design as the new concept of sustainability design," IOP Conf. Ser. Earth Environ. Sci., vol. 729, no. 1, p. 12095, 2021, doi: 10.1088/17551315/729/1/012095.

[21] I. T. Alsedrah and E. A. Hacine Gherbi, "Impact of COVID-19 pandemic on total market trade value (institutional investors vs noninstitutional investors)," J. Sustain. Financ. Invest., pp. 1-13, Mar. (2021), doi: 10.1080/20430795.2021.1905412.

[22] A. Jauhari and F. Ayu, "The Development of Information Systems for Measuring Student Performance at MTs Al-Azhar Paseseh Tanjung Bumi," vol. 04, no. 01, pp. 1-4, (2019).

[23] R. Fauzan, D. Siahaan, S. Rochimah, and E. Triandini, "Use Case Diagram Similarity Measurement: A New Approach," in 2019 12th International Conference on Information \& Communication Technology and System (ICTS), 2019, pp. 3-7, doi: 10.1109/ICTS.(2019).8850978.

[24] F. Zulfa, D. O. Siahaan, R. Fauzan, and E. Triandini, "Inter-Structure and Intra-Structure Similarity of Use Case Diagram using Greedy Graph Edit Distance," in 2020 2nd International Conference on Cybernetics and Intelligent System (ICORIS), (2020), pp. 1-6, doi: 10.1109/ICORIS50180.2020.9320840. 